УДК 373.015.31:796

DOI:

Юрій Примаченко, студент ФК-31Б Інституту фізичної культури $i$ здоров’я Дрогобицького державного педагогічного університету імені Івана Франка

\title{
РОЗВИТОК ОРГАНІЗАЦЙНОЇ РОБОТИ З ФІЗИЧНОЇ КУЛЬТУРИ У ЗАГАЛЬНООСВІТНІХ ШКОЛАХ
}

У статті висвітлюється сучасний етап розвитку фізичної культури. Засвідчено головні завданя иієї галузі і організачія фізкультурно-оздоровчої роботи. Приділяється значна увага у фізичному вихованні учнів та молоді. Акцентовано на застосуванні інноваційних технологій, які сприяють не лише удосконаленню рухових якостей та дотриманню здорового способу життя, але й підвищенню мотивачії до занять фізичною культурою та спортом. Обгрунтовано позитивні зміни в змісті, організації та технології навчання фізичної культури.

Ключові слова: фізичне виховання; інноваційні технології; навчання; учні; фізичні якості; професійна діяльність; здоров'я.

Jim. 9.

Yuriy Prymachenko, Student FK-31B Institute of Physical Education and Health Drohobych Ivan Franko State Pedagogical University

\section{DEVELOPMENT OF ORGANIZATIONAL WORK OF PHYSICAL CULTURE IN GENERAL EDUCATION SCHOOLS}

The article analyzes the direction of work of each school as improving the quality of education through the use of innovative technologies at lessons and during extracurricular activities. Therefore, a modern educator must have a thorough knowledge of these technologies and apply them successfully into their lessons. The teacher, using modern technologies, can improve not only physical qualities, but also develop the creative potential of students.

Physical education is a part of general education and is therefore characterized by all the common features inherent in a pedagogical process aimed at solving clear real-world problems. The main focus of physical education is the formation of a healthy, mentally prepared, physically advanced and prepared for the future profession of man. High mental load at school, lack of additional motor activity, low mobility of life, poor diet, negatively affects the health of students, the majority of schoolchildren's eyesight deteriorates, cardiovascular and respiratory activity, metabolism is impaired, the body's resistance to disease is reduced, which causes their health to deteriorate.

In order to promote the children's health you need to engage the students with a strong interest into exercise at school and at home. First, you need to use all forms of physical education at school, as well as independent exercise at home to improve physical activity, promote health, and improve the physical fitness of students. Physical education of the students on their own is the moral and volitional qualities of the individual, the need for daily exercise, vital motor actions and ability to perform them in various conditions, improved motor qualities. But because of the lack of time allocated to physical education, these issues cannot be resolved by the school alone.

Keywords: physical education; innovative technologies; teaching; pupils; physical qualities; professional activity; health.

П остановка проблеми. Проблемі здоров'я суспільства сьогодні приділяється величезна увага проводяться дослідження щодо можливостей збереження здоров'я дітей у сучасних умовах, досліджується критерій визначення рівня здоров'я та механізмів його зміцнення [3]. Фізичне виховання учнів загальноосвітніх шкіл - це невід'ємна складова освіти, яка дає можливість кожній дитині здобути науково обгрунтовані знання про здоров'я i способи його зміцнення, методи організації змістовного дозвілля що спрямовані на створення фізичного, соціального здоров'я, вдосконалюючи фізичну та психологічну підготовку до активного тривалого життя та професійної діяльності.
Аналіз основних досліджень. Основою нашого дослідження склали роботи, присвячені проблемі використання інноваційних технологій в системі фізичного виховання дошкільнят О. Лахно, молодших школярів, Н. Москаленко, Н. Павлова, I. Хрипко, дітей середнього і старшого віку, в шкільному віці О. Андрєєва, Ю. Васьков, Г. Глоба, Д. Слісєєва, В. Маринич) та інші. Назване дослідження розвитку організаційної роботи фізичного виховання залишається недостатньо вивченим.

Визначним завданням школи є зміцнення здоров'я та підтримки правильному фізичному розвитку учнів - фізичний стан дитини, його здоров'я - це основа, на якій можна розвивати 
всі його сили та можливості, в тому числі розумові. Звісно, що коли діти мало рухаються, вони відстають у розвитку від своїх однолітків, які мають регулярний руховий режим. Відомий педагог В.А. Сухомлинський приділяв велике значення діяльності школи та вчителів, спрямованих на оздоровлення школярів, особливо учнів початкових класів. Він вважав, що турбота про здоров'я дітей - найважливіше завдання вчителя [5]. Ціль запровадження інноваційних програм у фізичному вихованні школярів, як зазначає Н. Москаленко, забезпечує оздоровлення всіх складових здоров'я - психічного, соціального, фізичного [4].

Відповідно до "Положенням про фізичне виховання учнів загальноосвітньої школи”, система фізичного навчання та заняття спортом для учнів включає в себе наступні суміжні форми:

- уроки фізкультури;

- фізична та оздоровча функція в ході шкільного дня (гімнастика перед уроками, фізкультурні хвилинки під час уроків, ігри і фізичні вправи на перервах);

- позакласні заняття спортом - масова робота (заняття в кружках фізкультури та спортивних секцій, спортивних змаганнях);

- самостійні заняття учнів, фізичних вправ дома, на шкільних та дворових майданчиках, на стадіонах та інше.

Основна мета позакласної фізкультурноспортивної роботи полягає в тому, щоб залучити кожного школяра до самостійного, щоденного виконання фізичних вправ [1]. Ослаблення рухової активності не тільки формує до порушення нормального перебігу метаболічних процесів росту і розвитку, а й є причиною невротичного стану школярів, виявляється в легкій збудливості, дратівливості, неуважності, неадекватної реакції тощо.

Так, у режимі шкільного дня заняття в основному оздоровчі, спрямовані на підтримання робочого стану учня протягом дня. Особливо позакласні заняття спрямовані на формування рухових навичок, характерних для істинного виду спорту, розвиток рухових якостей. Але основною формою організації занять 3 фізкультури в школі $\epsilon$ урок, який класифікується за його змістом та завданнями.

Метою дослідження $є$ визначення шляхів впровадження інтерактивних технологій та інноваційних методів навчання для зміцнення здоров'я навчання, освіти і розвитку дітей та формування стійкої мотивації учнів до систематичної і самостійної фізичної культури.

Виклад основного матеріалу. Організація занять фізичною культурою є важливою ціллю в теорії фізичної культури, оскільки вирішення завдань, пов'язаних з фізичною культурою, багато в чому залежить від того, як організований навчальний процес.

Процес фізичної культури виконується шляхом послідовних тренувань. Кожне заняття є відносно самостійною ланкою в процесі, пов'язаною 3 попередніми та наступними подібними заняттями. Усі заходи повинні сприяти цілям фізичного розвитку рухових навичок.

Урок фізичної культури - це основна форма фізичного виховання для учнів. Він забезпечує фізичне виховання, загальну фізичну підготовку до будь-якої діяльності і відрізняється найбільшим багатством змісту. Під час уроку діти беруть участь у різних видах спортивних вправ, опановують основи техніки, досягають більш високого рівня розвитку рухових навичок, знайомляться з різними видами спорту [8].

Вимоги до уроку сучасної фізичної культури:

- враховувати мотивації та інтереси учнів до занять фізичними вправами;

- організація самостійної діяльності учнів, що забезпечується постійним навчанням, закріпленням за допомогою вчителя навичок та роботи 3 навчання, прийомів самоконтролю та самовиховання. Все це необхідно для пояснення необхідності систематичних занять фізичними вправами;

- обов'язкове використання різних форм, методів і прийомів організації;

- досягнення оптимальної рухової активності протягом усього уроку;

- створення раціональних умов для проведення уроку матеріальними, естетичними та моральнопсихологічними вимогами.

Тому основна мета уроку фізичної культури забезпечити учням сприятливі умови для успішного завершення навчальної програми. У цьому випадку урок - це лише форма організації навчальної діяльності вчителів та учнів, в рамках якої здійснюється їх взаємо узгоджена діяльність, спрямована на оволодіння знаннями, вміннями та навичками, підвищення рівня розвитку фізичних якостей учнів.

Таким чином, фізичне виховання здійснюється за допомогою фізичних вправ для досягнення бажаних змін адаптації в стані учнів. Але якщо враховувати лише зміни, що відбуваються в організмі в цьому процесі, а не в індивіда в цілому, це може призвести до спотвореного і занадто вузького розуміння фізичного виховання.

Актуалізація сучасного змісту шкільної освіти, особливо фізичного виховання, має на меті підвищити вимоги до загальної та спеціальної 
теоретичної та практичної підготовки фахівців, які організовують рухову активність дітей у різних видах навчання шкіл.

Педагогічний процес фізичного виховання відбувається шляхом використання різних форм занять, на яких учні опановують предмет фізичної культури, роблячи своїм надбаням, формуючи i збагачуючи свою особисту фізичну культуру. У сучасному світі освіта - це соціальна та духовна опора життєдіяльності людей.

Для сучасного суспільства впровадження інноваційних технологій в освіту $є$ не лише теоретичним, а й практичним, оскільки в умовах глобалізації воно пов'язане з його історичним розвитком та перспективами “передових технологій”.

“Інноваційні технології" - відносно нове поняття для сфери освіти, включаючи фізичне виховання. Модернізація фізкультурної освіти заснована на теоретичному і експериментальному обгрунтуванні організаційно-методичних підходів, дозволяючи визначити цільову спрямованість фізичного виховання, оздоровчої, адаптивної фізичної культури і масового спорту. Вживання сучасних інноваційних технологій, зміна змісту суті фізичного вдосконалення учнів засновані на використанні комплексної інформації, що дозволяє врахувати вікові відмінності школярів і їх індивідуальні особливості [2]. Під інноваційною діяльністю розуміється діяльність, направлена на реалізацію накопичених досягнень (знання, технології, устаткування) з метою здобуття нових або додаткових послуг з новими якостями.

Нововведення, в яких розвиваються педагогічні технології, не народжуються самі по собі, вони є результатом наукових досліджень та передового освітнього досвіду. 3 точки зору навчального процесу поняття “інновація” означає впровадження нової мети, змісту, методів і форм навчання та виховання, організацію спільної діяльності вчителя і учня що вчиться.

Тому інноваційна діяльність вчителя спрямована на трансформацію існуючих форм та методів виховання, створення нових цілей та засобів для їі реалізації, щоб вона становила один із видів продуктивної діяльності творчих людей.

Інноваційний педагогічний процес - цілісний навчально-виховний процес, що відображає єдність і взаємозв'язок виховання та навчання, котрий характеризує спільну діяльність співпрацею та спільною творчістю цих суб'єктів, сприяючи найбільш повному розвитку i самореалізації особистості учнів [7].

Заходи із збереження фізичного здоров'я дітей $\epsilon$ одним із основних напрямків роботи загальноосвітніх навчальних закладів. Піклуватися про фізичне здоров'я, формувати психічні та фізичні якості необхідно для фізичної культури та спорту. Збереження фізичного, психічного та соціального здоров’я дітей - одне з найважливіших завдань нашого суспільства.

Основні причини такої ситуації, на думку дослідників, таких як Г.П. Грибан, В.П. Губа, Т.Ю. Круцевич, Л.І. Лубішева, О.М. Бацина та ін. - це недостатня фізична активність протягом усього життя освіти в навчальних закладах, через недосконалість діючих національних навчальних програм з фізичної культури та відсутність культури здорового способу життя.

В останні роки процес ефективної теоретичної підготовки знань привернув увагу науковців. Аналіз спеціальної літератури дає змогу стверджувати, що велике значення має формування знань у галузі фізичного виховання учнів загальноосвітніх шкіл. Однак на сучасному етапі планування, організація та методика теоретичного викладання в системі курсів фізичної культури $є$ проблематичними. Формування знань має здійснюватися шляхом розвитку творчої діяльності серед учнів шляхом інтегрованих заходів, включаючи пізнання, спілкування, гру та наполегливу працю. Потребує вивчення питання формування теоретичних знань, які $є$ передумовою виховання потреби у заняттях фізичними вправами, глибокого і стійкого інтересу.

Важливо зазначити, що на думку фахівців В.Г. Ареф'єв, Г.А. Єдинак, Б.М. Шиян, знання сприяють якісному оволодінню руховими навичками, формуванню потреби до фізичного вдосконалення, усвідомленого ставлення до свого здоров'я [9].

Таким чином, особлива увага приділяється проблемі пошуку інноваційних підходів до свідомого ставлення до фізичного виховання та спорту школярів. Інноваційні педагогічні технології можна класифікувати на основні групи:

- традиційні педагогічні технології;

- педагогічні технології, засновані на особистісно орієнтованому педагогічному процесі;

- педагогічні технології на основі активізації та інтенсифікації діяльності учнів;

- освітні технології, засновані на підвищенні ефективності управління та організації навчального процесу;

- освітні технології, засновані на дидактичному вдосконаленні та реконструкції матеріалів;

- технології навчання, розділені за предметом; - альтернативні педагогічні технології навчання; - вроджені педагогічні технології;

- педадогогічні технології навчання через розвиток. 
По-перше. Слід починати з визначення змісту кожної програмної теми та уточнення обсягу цього змісту з урахуванням пізнавальних можливостей учнів конкретного віку та допустимого ліміту часу для викладу відповідної інформації в процесі визначених занять. Потім необхідно намітити можливі взаємозв'язки і наступність змісту однорідної і суміжних тематик, представлених у програмах кожного окремого і різних класів. Це дозволяє об'єднати всю сукупність пропонованого програмою теоретичного матеріалу в цілісну систему знань, якою повинні оволодіти учні в межах конкретної теми, розділу програми, річного циклу, навчання в загальноосвітньому закладі.

По-друге. Визначаючи місце конкретних предметів у навчально-виховному процесі, необхідно враховувати терміни та педагогічну спрямованість змісту уроків з різних предметів. Це дозволить використати міжпредметну інтеграцію змісту теоретичної підготовки учнів, щоб показати учням практичну важливість засвоєння теоретичного матеріалу з метою підвищення ефективності навчання знань.

По-третє. Обсяг теоретичного матеріалу в обсязі повинен бути спланований у частинах, які відповідають структурі та змісту конкретного уроку, не приносячи шкоди фізичним навантаженням і якими учні можуть засвоїти протягом запланованих годин. Систематичне представлення їх на серії уроків забезпечує систематичні знання та сприяє ефективності їх засвоєння.

По-четверте. Один 3 головних ознак повноцінності системи теоретичної підготовки чіткість визначення завдань. В їх формулюваннях повинно бути 3 якомога більшою визначеністю вказано, яку передбачається засвоїти інформацію, яке особистісне значення матимуть формуються знання, яким чином отримані знання можна реалізувати з фізкультурної діяльності в сьогоденні і майбутньому [6].

Інноваційні педагогічні технології підпорядковані конкретній меті і дають позитивний результат у спільній роботі педагогів та учнів, спрямовані на впровадження нововведень у змісті, методах, формах та засобах навчально-виховної роботи.

Характеристиками інноваційних технологій $є$ :

1. Концептуальність (використання певної наукової концепції чи системи ідей).

2. Інновації у створенні, сприйнятті, розвитку та оцінці інновацій; впровадження та поширення освітніх інновацій.

3. Спроможність - запорука досягнення цілей; проектування педагогічногопроцесу,його алгоритмізація.
4. Систематизація (наявність системних особливостей: логіка процесу, взаємозв'язок усіх компонентів, цілісність).

5. Легкість управління (постановка цілей, постійний зворотній зв'язок, покрокова діагностика, корекція результатів).

6. Ефективність (ефективність за рахунок результатів та оптимальність витрат, забезпечення досягнення певного рівня підготовки).

7. Відтворюваність (можливість використання інноваційних технологій в інших подібних навчальних закладах).

Розробка та впровадження інноваційних педагогічних технологій активізують діяльність дослідників та практиків у пошуку найбільш ефективних форм, інструментів та методів підвищення ефективної діяльності.

Це припускає використання новітніх досягнень науки i практики 3 метою виключення невиправданих витрат часу i ресурсів; прогнозування і проектування діяльності того, хто навчає, і тих, кого навчають, з метою запобігання ії корекції по ходу виконання; використання засобів інформаційних технологій.

\section{Висновки.}

1) Фізичне виховання - навчальний процес спрямований на фізичний розвиток, функціонального вдосконалення організму, засвоєння основних життєвих умінь, навичок і супутніх знань для успішності подальшої професійної діяльності.

2) Основна мета уроку фізичного виховання в школі - зміцнення та підтримка здоров'я, забезпечення загальної фізичної освіти в гармонії 3 повним розвитком фізичних здібностей та формуванням якостей особистості.

3) Впровадження інноваційних технологій дає змогу змінити традиційне відчуття уроку фізкультури в школі, підвищує емоції та насиченість та зацікавленість учнів до уроку. Завдяки використанню інноваційних технологій мотивація учнів до фізичного виховання в школі зростає, а відвідуваність учнів на уроках фізичної культури відповідно зростає.

4) Впровадження інноваційних технологій та їх елементів на уроці фізичної культури дозволяє збільшити обсяг фізичної активності дітей на уроці фізичної культури, дозволяє краще вирішити проблему уроку завдяки активності учнів на уроці. Також можливо краще вирішити проблеми фізичного виховання, а саме зміцнення здоров'я, поліпшення функціональності організму, формування мотиваційних параметрів для фізичного та духовного розвитку. Інноваційні 
технології допомагають знизити ризик захворювання, досягти та підтримувати певний рівень рухових навичок, підвищити рівень загальної та спеціальної підготовки та працездатності функціональних систем організму, розвиток сили різних груп м'язів та розвиток моторики для вирішення спортивних завдань на більш високому рівні. Тому впровадження інноваційних технологій та їх елементів на уроках фізичної культури дає змогу надалі вирішувати проблеми фізичного виховання, підвищувати інтерес до уроку фізичної культури в школі, учні займаються фізичною активністю, покращують здоров'я та розвивають фізичні якості.

5) Дослідження показало, що більшість викладачів фізкультури не дотримуються навчальної програми і майже завершують іiі вправними орієнтаціями на здоров'я (моделювання, аеробіка, спорт тощо).

6) Що стосується зміни традиційного змісту уроків на уроках з елементами інноваційної технології, за допомогою систематичних модифікаційних вправ можна значно підвищити рівень рухової активності школярів, поліпшити функціональну активність організму та забезпечити адекватний фізичний розвиток

\section{ЛІТЕРАТУРА}

1. Ведмеденко Б.Ф. Теорія і методика виховання інтересу учнів до заняття фізичною культурою: дис...докт.пед.наук. Київ, 2005. 701 с.

2. Гільова І. Впровадження інноваційних технологій та їх елементів на уроках фізичної культури. Фізичне виховання в школі.2017. №3 С.22-24.

3. Заклюжний В.Л. Впровадження інноваційних технологій в системі роботи фізкультурно-оздоровчого комплексу. Фізичне виховання в школі. 2018. №3. С.912.

4. Москаленко Н. В. Теоретико-методичні засади інноваційних технологій в системі фізичного виховання молодших школярів: автореф. дис. на здобуття наук. ступеня доктора наук з фіз. вих. та спорту: спец. 24.00.02 “Фізична культура, фізичне виховання різних верств населення”. Національний університет фізичного виховання і спорту України. Київ, 2019. 42 с.

5. Присяжнюк С.I. Фізичне виховання молоді. Київ, 2017.504c.

6. Черних В.П., Кайдалова Л.Г, Толочко В.М., Вахрушева Т.Ю. Освітні інновації в Національному фармацевтичному університеті: навч.-метод. посіб. Харків, 2005. С. 20-21.

7. Чернова А.В. Історія становлення поняття педагогічна технологія. Науковий вісник південноукраїнського педагогічного університету. 2016. №2. С. $32-35$.
8. Шапран О.І., Доброскок І.І., Коцур В.П., Нікітчина С.О. Інноваційні педагогічні технології: теорія та практика використання у вищій школі: монографія. ПереяславХмельницький, 2008. 285 с.

9. Шиян Б.М. Теорія і методика фізичного виховання школярів. Тернопіль, 2019. 272 с.

\section{REFERENCES}

1. Vedmedenko, B.F. (2005). Teoriia i metodyka vykhovannia interesu uchniv do zaniattia fizychnoiu kulturoiu [Theory and methods of raising the students' interest in physical education]. Doctor's thesis. Kyiv, $701 \mathrm{p}$. [in Ukrainian].

2. Hilova, I. (2017). Vprovadzhennia innovatsiinykh tekhnolohii ta yikh elementiv na urokakh fizychnoi kultury [Introduction of innovative technologies and their elements in physical education lessons]. Physical education at school. No.3, pp.22-24. [in Ukrainian].

3. Zakliuzhnyi, V.L. (2018). Vprovadzhennia innovatsiinykh tekhnolohii v systemi roboty fizkulturno ozdorovchoho kompleksu [Implementation of innovative technologies into the system of work of the fitness center]. Physical education at school.No.3, pp.9-12. [in Ukrainian].

4. Moskalenko, N. V. (2019). Teoretyko-metodychni zasady innovatsiinykh tekhnolohii v systemi fizychnoho vykhovannia molodshykh shkoliariv [Theoretical and methodological foundations of innovative technologies into the system of physical education of younger students]. Extended abstract of Doctor's thesis. National University of Physical Education and Sports of Ukraine. Kyiv, 42 p. [in Ukrainian].

5. Prysiazhniuk, S.I. (2017). Fizychne vykhovannia molodi [Physical education of young people]. Kyiv, 504p. [in Ukrainian].

6. Chernykh, V.P., Kaidalova, L.H, Tolochko, V.M. \& Vakhrusheva, T.Iu. (2005). Osvitni innovatsii $v$ Natsionalnomu farmatsevtychnomu universyteti: navch.metod. posib. [Theoretical and methodological foundations of innovative technologies into the system of physical education of younger students]. Kharkiv, pp. 20-21. [in Ukrainian].

7. Chernova, A.V. (2016). Istoriia stanovlennia poniattia pedahohichna tekhnolohiia [History of formation of the concept of pedagogical technology]. Scientific Bulletin of the South Ukrainian Pedagogical University. No.2. pp. 32-35. [in Ukrainian].

8. Shapran, O.I., Dobroskok, I.I., Kotsur, V.P. \& Nikitchyna, S.O. (2008). Innovatsiini pedahohichni tekhnolohii: teoriia ta praktyka vykorystannia $u$ vyshchii shkoli: monohrafiia [Innovative pedagogical technologies: theory and practice of use in higher education: monograph]. Pereiaslav-Khmelnytskyi, 285 p. [in Ukrainian].

9. Shyian, B.M. (2019). Teoriia i metodyka fizychnoho vykhovannia shkoliariv [Theory and methodology of physical education of students]. Ternopil, 272 p. [in Ukrainian].

Стаття надійшла до редакції 04.09.2019 